\title{
Increasing Customer's Saving Interest through Religiusity, Product Perception and Knowledge
}

\author{
Dahrul Siregar ${ }^{1}$, Ahmad Harun Daulay ${ }^{2}$, Saparuddin Siregar ${ }^{3}$ \\ ${ }^{1,2}$ Universitas Medan Area, Indonesia \\ ${ }^{3}$ Universitas Islam Negeri Sumatera Utara, Indonesia \\ darulregar@gmail.com
}

\begin{abstract}
The number of Islamic banks is not significant with the Muslim population in this country. The efforts to increase the number of customers and use of Islamicl sharia products need to be increased. The aim of this study is to analyze the effect of religiosity, product perception and knowledge on people's saving interest in Islamic banking products. The target population and sample in this study are 135 Moslems by using purposive random sampling technique. Data collection using a questionnaire. The results showed that all independent variables of religiosity, product perception and knowledge have a positive and significant effect on saving interest in Islamic banking products. The most dominant variable in influencing consumers' interest in saving is product perception.
\end{abstract}

Keywords religiosity, product perception; knowledge; interests

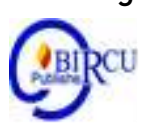

\section{Introduction}

Economic development cannot be separated from the development of the Islamic finance industry (Ahdan, 2020). There are many conventional banks also diversifies their products into Islamic products. Banks tries to provide mutual benefits for both banks and customers (Sakti, 2020). Islamic bank products are of course based on the principles of Islamic values Islam (Nur'aini Ika Ramadhani; Jeni Susyanti; M Khoirul ABS, 2019). This is due to the fact that the majority of the population in Indonesia is Moslem (Tripuspitorini, 2019). Efforts to stay survive must be made by banks by providing attractive offers to customers (Purwaliani, 2017).

Interest in saving in Islamic bank products has an important meaning for the progress of Islamic banks (Widowati, 2019). Saving interest or better known as buying interest is a desire for a product or service (Tjiptono, 2014). The desire of a customer will also be formed from the attitudes of others (Keller, 2012). However, a consumer who has his own thoughts and beliefs will certainly not be affected by the attitudes of other people. A customer's interest in saving will come arise when trust in Islamic banks is proven to be good for the customer (Durianto Darmadi, 2013).

Efforts to keep increasing the number of customers either new customer or existing customers to utilize the latest banking products by understanding the level of customer religiosity (Harahap, 2020). Religiosity means the level of confidence of customer trust or confidence in applying their buying and selling activities (Tripuspitorini, 2019). Run a business without breaking any values in customers' belief is very important (Yoganingsih, 2020). Furthermore, customers who have a high level of religiosity believe that life is not only for the world life, but this is also for the afterlife (Nur'aini Ika Ramadhani; Jeni 
Susyanti; M Khoirul ABS, 2019). Religiosity in customers tends to make customers welcome when banks offer various benefits of new products (Umiyati, 2018).

Not only efforts to understand the level of customer religiosity, but also efforts to increase interest in saving need to be made, it is by building product perceptions in customers' minds (Soesanto, 2016). It will be very hard to increase interest in saving if people's perceptions are still very low on knowledge of various sharia products (Hendrawan, 2018). It is no wonder to find the society's understanding is still low since conventional banks have been so close to the community (Ibrahim, 2017). A customer who has a product perception will find it is easy to pick and choose product-related information, to manage new information and even interprete the information (Keller, 2012). In general, the public's perception of this sharia product is specifically for Muslim customers only. Then the profit sharing that will be received is still confusing. Because the community is difficult to calculate how much profit they will receive. In contrast to conventional banks set the interest rate system.

The last factor that affects customers' interest in saving on Islamic bank products is the knowledge they have (Hakim, 2019). Customer knowledge of sharia products will be seen from their ability to minimize the level of risk that exists (Ratnasari, 2018). The effort to increase knowledge of Islamic bank products is namely by supporting religious activities actively (Nugroho, 2019). Furthermore, banks are also actively do socialization due to the advantages that exist in Islamic banking products compare with conventional banks (Syahriyal, 2019). So that the product knowledge possessed by customers has an important meaning for the banks (Warnaby, 2008).

For Islamic banks, of course this research is very important. Because it can help to formulate various policies in recognizing and increasing the number of new customers related to Islamic bank products. Then the aim of this research is to analyze the effect of religiosity, product perspectives and knowledge on interest in saving in Islamic banking products.

\section{Review of Literatures}

\subsection{Interest in Saving}

In the world of marketing, consumers are assets that must be maintained and maintained their existence in order to remain consistent with the products we produce. One form of commitment that must be given to consumers is by providing good and satisfying services and leading to the creation of customer loyalty (Romdonny, 2019). A customer's interest in saving is the same as a consumer's interest in buying products and services. It is very complex and complicated to understand the problem of consumer buying interest. However, for marketers, it needs special concern in order to be able to combine various stimuli in increasing consumer buying interest. Purchase interest can be defined as the stages that exist in consumers that form a choice and at last decide to buy from many options of products and services offered. Furthermore, consumers will sort the products that best suit their needs (Pramono, 2012). For (Ferdinand, 2014) purchase interest is the emergence of consumer behavior on the response of an object which is reflected in the desire to buy it.

According to(Assael, 2010) there are some factors that must be considered by marketers in increasing costumer buying interest. They are:

a. Environment

Costumer can not live alone but in need of others. The environment that exists around costumer will influence the buying interest in a product or service with a certain brand. 
b. Marketing Stimulus

When the work environment is unable to influence a costumer's buying interest, so any stimulus that costumer gets will influence his buying interest. This stimulus will go to costumer's five senses.

\subsection{Religiosity}

Everybody has values of belief in their religion. This aspect of religion convinces everyone's heart to behave and act in accordance with the demands of his holy book. This forms a character in socializing and doing business. This concept is known as religiosity (Karim, 2011). Then according to (Nur;aini Ika Ramadhani; Jeni Susyanti; M Khoirul $\mathrm{ABS}, 2019)$ to measure the level of religiosity of a customer consists of the following aspects of belief, religious practice, experience, religious knowledge. Previous research results indicate that religiosity has a significant effect in increasing customer interest in using Islamic bank products (Wahyoedi, 2017)(Kusuma, 2017)(Singh, 2019)(Streimikiene, 2020). It shows that better religiosity means higher interest of costumer in saving Islamic bank products.

H1: Religiosity has a positive and significant influence on customers' saving interest

\subsection{Product Perception}

Customer perceptions about banking products will vary from one another. This perception arises as a result of the sensation of a customer's senses (Setiadi, 2013). For this reason, the sensation of the customer should be stimulated. Then the consumer's perception of a product can be interpreted as the process of giving value or meaning to a stimulus by customers (Wenas, 2015). There are several things that must be considered in building perceptions towards customers, including the location of the bank, the facilities owned by the bank, the products offered, attractive advertisements, reliable salespeople and competitive prices compared to other banks (Yriyono, 2006). So, it is important for banks to see which dominant factors in building product perceptions to customers (Amali, 2018). The results of previous research conducted by (Agyeiwaa, 2015)(Krizanova, 2018) (Lee, 2019)(Indawati Lestari; Nasib, 2019)(Lubis, 2020) stated that product perception has a significant effect in increasing consumer interest.

H2: Product perception has a positive and significant influence on customers' saving interest

\subsection{Knowledge}

The knowledge of a consumer consists of the benefits of the product, how to use it and how to buy it (Sumarwan, 2011). Having knowledge will avoid customer chooses products with low benefit value. Costumer knowledge (Huriyati, 2014) has several dimensions, including knowledge of the subject of products and services, knowledge of the object of a product and service and knowledge of other information related to products and services. The results of research conducted by (Sabil, 2013)(Stankevich, 2017)(Ateke Brown Walter; Didia, 2018)(Safitri, 2018) state that costumers knowledge has an impact in increasing costumer interest.

H3: Knowledge has a positive and significant influence on customers' saving interest 


\subsection{Theoretical Framework}

In providing a research flow to clarify the existing problem, the theoretical framework in this study can be described as follows:

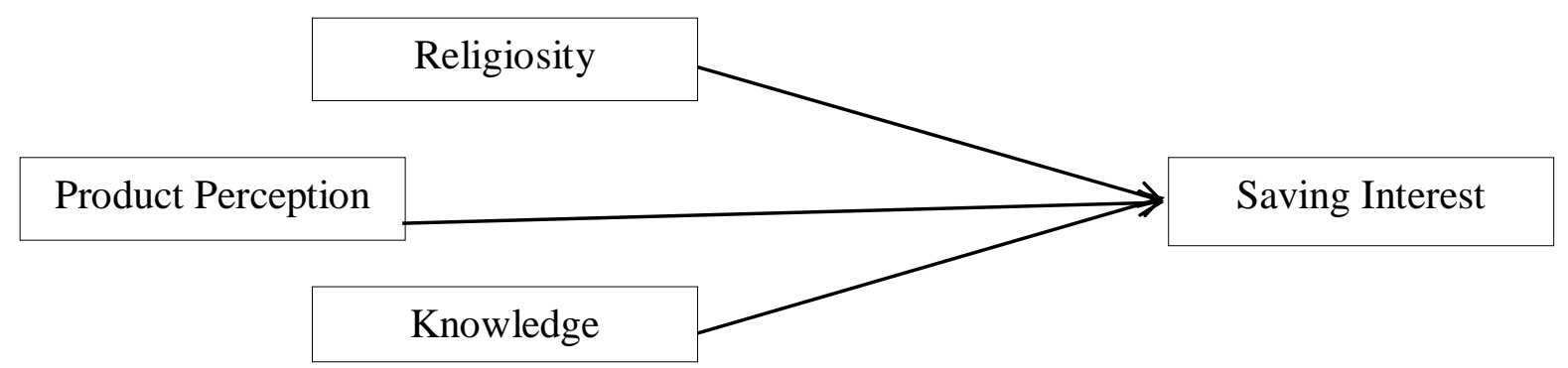

Figure 1. Theoritical Framework

\section{Research Methods}

This research is conducted in Langkat District, North Sumatra Province. The object of research is Muslim costumers. Population and sample of 135 respondents selected by purposive random sampling. Then the data collection uses a questionnaire that has been compiled based on the research indicators of each variable. Finally, the data analysis used is multiple linear regression analysis.

\section{Results and Discussion}

\subsection{Content of Results and Discussion}

The results of data processing can be shown in the table below:

Table 1. Results of Data Processing

\begin{tabular}{|l|c|c|l|}
\hline Effect & $\mathrm{t}_{\text {count }}$ & $\mathrm{Sig}$ & \multicolumn{1}{|c|}{ Result } \\
\hline Religiosity - Saving Interest & 3,172 & 0,00 & Positive and Significant \\
\hline Product Perception - Saving Interest & 3,945 & 0,000 & Positive and Significant \\
\hline Knowledge - Saving Interest & 2,854 & 0,000 & Positive and Significant \\
\hline
\end{tabular}

\subsection{The Effect of Religiosity on Saving Interest}

The results of the study provide evidence that a customer's religiosity affects the interest in saving Islamic bank products. This result can be seen from the value of tcount $3.172>\mathrm{t}$ table $1.978(\mathrm{n}-\mathrm{k}=135-4=131)$. The result of this study is in line with the results of research conducted by (Wahyoedi, 2017)(Kusuma, 2017)(Singh, 2019)(Streimikiene, 2020) which states that the increase one's religiosity will increase saving interest in Islamic bank products. The implication of the findings in this study shows that customers who practice the religion through religious activities can encourage a customer to be more familiar with sharia products than conventional banks.

\subsection{The Effect of Product Perception on Saving Interest}

The product perception variable in this study has a positive and significant effect on the saving interest in Islamic bank products. The product perception has a value of tcount $3,9,45>$ ttable $1,978(n-k=135-4=131)$. So, the hypothesis which states that product perceptions have a positive and significant effect on customers' interest in saving is accepted. Furthermore, this research is in line with the results of previous research 
(Agyeiwaa, 2015)(Krizanova, 2018)(Nasib, 2019)(Lee, 2019)(Indawati Lestari; Nasib, 2019)(Lubis, 2020) which states that better product perception increases costumer interest. The finding in this study is that customer have assumed that these Islamic bank products are especially for Moslem customers. Then the profit sharing received by costumers is difficult to predict, it is not the same with the interest rates on conventional bank products.

\subsection{The Influence of Knowledge on Saving Interests}

The results of data analysis indicate that consumer knowledge has a positive and significant influence on the saving interest in Islamic bank products. The t-count value for the knowledge variable is $2.854>1.978(\mathrm{n}-\mathrm{k}=135-4=131)$. This result accepts the research hypothesis which states that knowledge has a positive and significant influence on saving interest of Islamic bank products. This result is in accordance with the results of previous research (Nugroho, 2019)(Sakti, 2020)(Ulfha, 2020) which states that customer knowledge is able to increase saving interest in sharia products. The implication of the findings in this study is that when the socialization by banks in introducing Islamic products/ sharia products through recitation only, it is not effective. Actually, the knowledge possesed by community is that the Islamic bank community is for profit sharing, while conventional banks use interest rates. So, the effort that must be made is not just do socialization but by asking customers to migrate to a sharia-based financing system that prioritizes the success of living in the world and in the hereafter.

\section{Conclusion}

The writer concludes all independent variables of religiosity, product perception and knowledge have a positive and significant influence on the saving interest in Islamic banking products. The most dominant variable in influencing consumers' saving interest is product perception. Managerial implications that can be taken, especially Islamic banks, should be more intense in building the perception of Sharia products. In addition, the reason conventional banks are dominant in controlling the share of the banking market in the country, as their existence of certain cooperation contracts in terms of paying employees' salaries. It is better if it is possible to build partners among and with Islamic banks since customers' knowledge is actually already good, but conditions in the company oblige the use of conventional bank products only.

\section{References}

ABS, Nur'aini Ika Ramadhani; Jeni Susyanti; M Khoirul. (2019). Analisis Pengaruh Tingkat Religiusitas, Pengetahuan Dan Lingkungan Sosial Terhadap Minat Menabung Mahasiswa Di Bank Syariah Kota Malang (Studi Kasus Pada Mahasiswa Banyuwangi Di Kota Malang). E - Jurnal Riset Manajemen, 8(19), 79-87.

Agyeiwaa, C. K. A. H. H. A. (2015). Consumer Perception of Product Quality. Microeconomics and Macroeconomics, 3(2), 25-29. https://doi.org/10.5923/j.m2economics.20150302.01

Ahdan, M. C. N. A. R. (2020). Peran Literasi Keuangan Syariah dalam memoderasi Pengaruh Demografi terhadap Minat Menabung Pada Perbankan Syariah. Jurnal Manajemen Motivasi, 16, 1-7.

Amali, W. M. M. (2018). Pengaruh Persepsi Konsumen terhadap Keputusan Pembelian Ulang pada Indomaret Kecamatan Sungai Bahar. EKONOMIS: Journal of Economics and Business, 2(2), 235-244. https://doi.org/10.33087/ekonomis.v2i2.47 
Assael. (2010). Consumer Behavior and Marketing Action.Fifth Edition. Cincinnati Ohio: South-Western College Publishing.

Ateke Brown Walter; Didia, J. U. D. (2018). Consumer Knowledge and Purchase Intention of Healthcare Product Consumers in Rivers State. Journal of Business and Law Research, 6(January), 1-7.

Durianto Darmadi. (2013). Strategi Menaklukkan Pasar Melalui Rset Ekuitas dan Perilaku Merek. Jakarta: PT Gramedia Pustaka Utama.

Ferdinand, A. (2014). Metode Penelitian Manajemen. Semarang: BP Universitas Ngeri Semarang.

Hakim, T. O. F. A. P. R. (2019). Analisis Pengetahuan tentang Perbankan Syariah Santri Pondok Pesantren Al-Ittihad Mojokerto dan Pengaruhnya terhadap Minat Menabung di Bank Syariah. Iqtishodia: Jurnal Ekonomi Syariah, 4(2), 181-206. https://doi.org/10.35897/iqtishodia.v4i2.230

Harahap, T. S. R. (2020). Pengaruh Persepsi Dan Religiusitas Nasabah Terhadap Keputusan Memilih Produk Gadai Emas Di Pt Bank Syariah Mandiri Kantor Cabang Pembantu Medan Iskandar Muda. AL-INFAQ: Jurnal Ekonomi Islam, 1(1), 1-21.

Hendrawan, I. B. (2018). Pengaruh Persepsi Masyarakat Batam Tentang Bank Syariah Terhadap Minat Menggunakan Produk Bank Syariah. Journal of Applied Business Administration, 1(2), 209-218. https://doi.org/10.30871/jaba.v1i2.621

Huriyati, R. (2014). Bauran Pemasaran dan Loyalitas Konsumen. Bandung: Alfabeta.

Ibrahim, H. R. C. (2017). Pengaruh Produk Bank Syariah Terhadap Minat Menabung Dengan Persepsi Masyarakat Sebagai Variabel Moderating Di Pati. Equilibrium: Jurnal Ekonomi Syariah, 4(1), 43-61. https://doi.org/10.21043/equilibrium.v4i1.1837

Indawati Lestari; Nasib, S. C. A. S. A. ; I. E. (2019). Trust Identification And Smartphone Purchase Decisions (Structural Equation Modeling Approach). In International Journal of Civil Engineering and Technology (IJCIET) (Vol. 10, pp. 1020-1032).

Karim, A. (2011). Bank islam: Analisis Fiqih dan Keungan. Jakarta: Rajawali Press.

Keller, P. K. K. L. (2012). Manajemen Pemasaran Edisi 12. Jakarta: Erlangga.

Krizanova, K. V. J. K. A. (2018). Consumer Perception of Private Label Products: An Empirical Research. Journal of Competitiveness, 10(3), 149-163. https://doi.org/10.7441/joc.2018.03.10

Kusuma, A. P. N. A. H. H. (2017). The Influence Of Religiosity And Self-Efficqacy On The Saving Behavior Of The Slamic Banks. Banks and Bank Systems, 12(3), 35-47. https://doi.org/10.21511/bbs.12(3).2017.03

Lee, S. Y. J. (2019). The Effects of Consumers' Perceived Values on Intention to Purchase Upcycled Products. Sustainability (Switzerland), 11(4), 1-20. https://doi.org/10.3390/su11041034

Lubis, I. L. S. C. N. Z. F. Z. R. D. D. S. (2020). The Role of Switching Barrier to Become Intervening Variables between Brand Image and Trust on User Loyalty Halal Labeled Cosmetics. International Journal of Advanced Science and Technology, 29(3), 13352-13359.

Nasib, B. (2019). Pengaruh Brand Awareness dan Loyalitas Merek Terhadap Keputusan Pembelian Sepeda Motor Yamaha Matic. Jurnal Manajemen Dan Keuangan, 8(1), 34-42.

Nugroho, F. M. P. T. A. (2019). Pengaruh Pengetahuan, Reputasi, Lingkungan Dan Religiusitas Terhadap Minat Pelajar Sekolah Menengah Kejuruan Prodi Perbankan Syariah Dalam Menabung Di Bank Syariah. Jurnal Ekonomi Islam, 10(1), 14-37.

Pramono, A. S. S. S. (2012). Pertimbangan Dalam Membeli Produk Barang Maupun Jasa. 
Jakarta: Intidayu Press.

Purwaliani, A. H. M. S. R. (2017). Peran Iklan Dalam Meningkatkan Minat Menabung Masyarakat Pada PT. Bank Syariah Mandiri Cabang Kota Langsa. Jurnal Ilmiah Mahasiswa (JIM), 1(1), 1-25.

Romdonny, J., and Rosmadi, M.L.N. (2019). Factors Affecting Customer Loyalty in Products. Budapest International Research and Critics Institute-Journal (BIRCIJournal). P. 337-343.

Ratnasari, A. H. R. D. (2018). Pengaruh Pengetahuan, Kualitas Pelayanan, Produk, dan Religiusitas terhadap Minat Nasabah untuk Menggunakan Produk Simpanan pada Lembaga Keuangan Mikro Syariah. Jurnal Ilmiah Ekonomi Islam, 4(02), 136-147. https://doi.org/10.29040/jiei.v4i02.307

Sabil, D. S. I. Z. (2013). Consumer Decisions toward Fashion Product Shopping in Indonesia: The effects of Attitude, Perception of Ease of Use, Usefulness, and Trust. Management Dynamics in the Knowledge Economy, 7(2), 133-146. https://doi.org/10.25019/mdke/7.2.01

Safitri, A. I. (2018). The influence of product price on consumers' purchasing decisions. Review of Integrative Business and Economics Research, 7(2), 328-337.

Sakti, I. F. M. Y. S. N. C. (2020). Pengaruh Pengetahuan Tentang Bank Syariah Dan Literasi Keuangan Terhadap Minat Menabung Siswa Di Bank Syariah. Jurnal Ekonomi Pendidikan Dan Kewirausahaan, 8(1), 53-66. https://doi.org/10.26740/jepk.v8n1.p53-66

Setiadi. (2013). Konsep dan praktek penulisan riset keperawatan (Ed.2). Yogyakarta: Graha Ilmu.

Singh, R. A. P. M. R. (2019). Religiosity And Consumer Behavior: A Summarizing Review. Journal of Management, Spirituality and Religion, 16(1), 32-54. https://doi.org/10.1080/14766086.2018.1495098

Soesanto, H. A. K. H. (2016). Analisis Pengaruh Persepsi Kualitas Pelayanan Dan Perceived Value Terhadap Kepuasan Religius Untuk Meningkatkan Minat Menabung Ulang (Studi Pada BNI Syariah Semarang). Jurnal Studi Manajemen \& Organisasi 13, 13(6), 14-27.

Stankevich, A. (2017). Explaining the Consumer Decision-Making Process: Critical Literature Review. Journal of International Business Research and Marketing, 2(6), 7-14. https://doi.org/10.18775/jibrm.1849-8558.2015.26.3001

Streimikiene, F. B. S. H. R. R. A. R. H. S. Z. A. C. D. (2020). Motives and Role of Religiosity towards Consumer Purchase Behavior in Western Imported Food Products. Sustainability (Switzerland), 12(1), 1-22.

Sumarwan, U. (2011). Perilaku Konsumen: Teori dan Penerapannya dalam Pemasaran. Bogor: Ghalia Indonesia.

Syahriyal, S. (2019). Pengaruh Persepsi Nilai Dan Pengetahuan Masyarakat Terhadap Minat Menabung Serta Dampaknnya Kepada Keputusan Menabung Pada Perbankan Syariah Di Banda Aceh. Jurnal Perspektif Ekonomi Darussalam, 4(1), 139-156. https://doi.org/10.24815/jped.v4i1.10930

Tjiptono, F. (2014). Pemasan Jasa - Prinsip, Penerapan, dan Penelitian. Yogyakarta.

Tripuspitorini, F. A. (2019). Pengaruh Religiusitas Terhadap Minat Mahasiswa Politeknik Negeri Bandung Untuk Menabung Di Bank Syariah. Jurnal Masharif Al-Syariah, 4(2), 54-69.

Ulfha, N. N. A. H. I. F. (2020). Pengaruh Religiusitas, Pengetahuan Perbankan, Pengetahuan Produk Perbankan, Pengetahuan Pelayanan Perbankan, Dan Pengetahuan Bagi Hasil Terhadap Preferensi Menggunakan Jasa Perbankan Syariah. 
ASSET: Jurnal Manajemen Dan Bisnis, 1(1), 15-25. https://doi.org/10.24269/asset.v1i1.2554

Umiyati, P. A. (2018). Inluence Of Religiosity Towards The Saving Interest At Islamic Banking With The Knowledge Of The People As Moderator Variable (Case Study On The People Of South Tanggerang City). Ikonomika, 3(1), 1-16. https://doi.org/10.24042/febi.v3i1.2229

Wahyoedi, S. (2017). The Effect of Religiosity, Service Quality, and Trust on Customer Loyalty in Islamic Banking in Bogor Indonesia. International Review of Management and Business Research, 6(August 2016), 1.

Warnaby, M. G. M. G. (2008). Exploring The Relationship Between Consumer Knowledge And Purchase Behaviour Of Value-Based Labels. International Journal of Consumer Studies, 32(5), 414-426. https://doi.org/10.1111/j.14706431.2008.00712.x

Wenas, O. T. R. J. J. R. (2015). Pengaruh Persepsi Konsumen Dan Kepercayaan Terhadap Penggunaan Jasa Asuransi Pada Asuransi Jasindo Manado. Jurnal EMBA, 3(3), 312321.

Widowati, E. P. R. (2019). Pengaruh Persepsi Nasabah BRI Pada Kualitas Layanan Terhadap Kepuasan Dan Loyalitas Nasabah BRI Kanca Wonosari. Jurnal Bisnis Teori Dan Implementasi, 10(1), 52-64.

Yoganingsih, M. R. R. T. (2020). Pengaruh Religiusitas, Pengaruh Sosial Dan Dukungan Pemerintah Terhadap Minat Menabung Di Bank Syariah Mandiri - Bekasi. Jurnal Ilmiah Akuntansi Dan Manajemen (JIAM), 16(2), 76-83.

Yriyono, S. (2006). Sukses Terpadu Bisnis Ritel. Jakarta: PT Elek Media Komputindo Kelompok Grmaedia. 